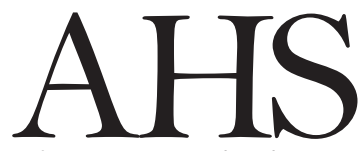

Advances in Horticultural Science

\title{
The impact of cumin essential oil on cold stored-radish tubers
}

\author{
S. Dehghanpour, M. Shamili (*), A. Mirzalaiyan-Dastjerdi \\ Horticulture Department, Faculty of Agriculture, University of Hormozgan, \\ Bandar Abbas, Iran.
}

Kew words: Antioxidant capacity, Malondialdehyde, protease, protein, total phenol content

OPEN ACCESS

(*) Corresponding author: $^{\text {shamili@ut.ac.ir }}$

Citation:

SHAMILI M., DEHGHANPOUR S., MIRZALAIYANDASTJERDI A., 2021 - The impact of cumin essential oil on cold stored-radish tubers. - Adv. Hort. Sci., 35(1): 33-42

Copyright:

(C) 2021 Shamili M., Dehghanpour S., MirzalaiyanDastjerdi A. This is an open access, peer reviewed article published by Firenze University Press (http://www.fupress.net/index.php/ahs/) and distributed under the terms of the Creative Commons Attribution License, which permits unrestricted use, distribution, and reproduction in any medium, provided the original author and source are credited.

Data Availability Statement: All relevant data are within the paper and its Supporting Information files.

Competing Interests:

The authors declare no competing interests.

Received for publication 22 May 2020 Accepted for publication 27 January 2021
Abstract: Notable biological compounds in radish, made it as one of the most popular crops in the raw vegetables global market. However, storing it under low temperature conditions is associated with browning and taste changing. The present research aimed to evaluate the effects of different concentrations of cumin essential oil $(0,1.56,3.13,6.25,12.5$ and $25 \mathrm{ppm})$ and the storage period $(0,3,6$ and 9 days) on antioxidant parameters of radish tubers under low temperature conditions. The results indicated declining trends in the $L^{*}$ and $a^{*}$ values, beside ascending trend in $b^{*}$ value after nine days of storage. However, over the storage period of tubers, these parameters increased in cumin essential oil treated tubers. According to our findings, the application of cumin essential oil increased protein content, but reduced the malondialdehyde content, polyphenol oxidase and peroxidase activities. The cold-stored radishes received the most effective treatment of cumin essential oil at the concentration of 12.5 and $25 \mathrm{ppm}$.

\section{Introduction}

Radish (Raphanus sativus L.), belongs to the Cruciferae family, is a part of the human diet worldwide. This root-product is usually used as a crunchy vegetable, mainly in salads (Banihani, 2017). Radish contains carbohydrates, sugars, dietary fibers, proteins, vitamins and minerals (Khattak, 2011). In addition, it has been found to be rich in some bioactive compounds, including isothiocyanates (e.g. indole-3-carbinol and sulforaphane) and glucosinolates (e.g. glucoraphanin, glucoerucin, glucobrassicin, glucoraphasatin, neoglucobrassicin, 4-methioxyglucobrassicin and 4-hydroxyglucobrassicin) (Malik et al., 2010; Ishida et al., 2015; Baenas et al., 2016), which prevent the proliferation of the colon (Nakamura et al., 2008), prostate (Steinbrecher et al., 2009), lung (Wang et al., 2014) and breast (Pawlik et al., 2017) cancer cell lines.

The global marketing of radish has improved due to be included in easy-to-prepare foods especially in the northern European countries like Holland and Germany (Salerno et al., 2005). However, the storage of radish under ambient conditions leads to shrinking and hence failing its 
marketing (Luegno and Calbo, 2001).

Low temperature conditions are commonly used in the food industry to maintain the quality of horticultural products in storage, reduce the respiration rate and delay metabolic processes (Patel et al., 2016). But lipid peroxidation, the most important deteriorating factor during low temperature storage, affects the nutritional value and sensory evaluation of food products (Liang et al., 2020), i.e radish lose up to $5 \%$ of its weight and $43 \%$ of its nutritional content after exposure to low temperature $\left(10^{\circ} \mathrm{C}\right)$ for 10 days (Del Aguila et al., 2006).

The antioxidants are essential compounds that prevent or delay the lipid peroxidation (Khalid et al., 2016). Food industries use artificial antioxidants such as BHA (Butylated hydroxylanisole), BHT (Butylated hydroxyltoluene), TBHQ (Tertiary-butyl hydroquinone), and PG (Propyl gallate) to extend the shelf life of cold-stored products. However, the side effects of these synthetic components have caused consumers to be concerned (Andre' et al., 2010; Liang et al., 2020) and drawn the attention of researchers to safe alternatives such as natural derived products. Plants essential oils (EOs) are a rich source of antioxidants which reduce the production of reactive oxygen species (ROS) or scavenge the formed ROS (Khalid et al., 2016).

Browning and taste changing are the main disorders which influence the quality of radishes under low temperatures (Del Aguila et al., 2008; Ramachandran et al., 2013). Using antioxidant compounds, such as citric acid and ascorbic acid (Del Aguila et al., 2006; Lee et al., 2007) or covering the tuber with chitosan (Ramachandran et al., 2013) have reduced the browning intensity under cold storage conditions. Packed radishes can also be stored for six days under low temperatures with no browning symptoms (Nicola et al., 2004; Ayub et al., 2013).

Plant EOs can serve as efficient strategies in the quality preservation in cold-stored horticultural products (Misharina and Samusenki, 2008). The Cumin (Cuminum cyminum L.), an herbaceous annual member of the Apiaceae family, is frequently used as flavor (Thippeswamy and Naidu, 2005). The main components of cumin EO are cuminal, cuminic alcohol, terpinene, safranal, p-cymene and pinene (Thippeswamy and Naidu, 2005; Ravi et al., 2013).

Despite several reports on the antimicrobial characteristics of cumin EO (Thippeswamy and Naidu, 2005; Gachkar et al., 2007; Milan et al., 2008; Dua et al., 2012), there is no research on its potential to serve as an antioxidant with ROS scavenging capacity, specifically in applying on cold-stored products. Therefore, the present research aimed to evaluate the effects of different concentrations of cumin EO, as an organic antioxidant compound, on the biochemical and antioxidant parameters of stored radishes under low temperature conditions.

\section{Materials and Methods}

\section{Plant material preparation}

Radish (Raphanus sativus L. var 'Cherry Belle') seeds were planted (October $1^{\text {st }} 2019$ ) in the research greenhouse ( $\mathrm{RH}=50 \%$, temperature: $26 \pm 1^{\circ} \mathrm{C}$ day $/ 20 \pm 0.5^{\circ} \mathrm{C}$ night, and $50 \%$ shade) at the University of Hormozgan $\left(53^{\circ} 33^{\prime} \mathrm{E} 28^{\circ} 30^{\prime} \mathrm{N}, 10 \mathrm{~m}\right)$, Iran. The plastic pots $\left(25 \times 18 \mathrm{~cm}^{2}\right)$ were filled by a media mixture (soil-sand-silt in 1:1:1 ratio). Daily drip irrigation system was used for all experimental units. The tubers were harvested 40 days later. The experiment was repeated next months (November $1^{\text {st }} 2019$ December $10^{\text {th }}$ 2019). The radish tubers were then transferred to the laboratory. After wards, wellformed and uniform tubers $\left(1.5 \times 1.5 \mathrm{~cm}^{2}\right)$ which were healthy, smooth, firm and free from decay, damage or cracks were selected, washed and dried.

\section{The experimental design}

The factorial experiment was a completely randomized design with six replications (10 samples per each experimental unit). The factors were cumin EO concentrations $(0,1.56,3.13,6.25,12.5$ and $25 \mathrm{ppm})$ and the storage period (0, 3, 6 and 9 days). The control (day 0 ) measurement was done before applying the treatments. The cumin EO was prepared from Zardband Pharmaceuticals industry, Tehran, Iran. The phytochemical and microbiological properties of the EO were described by Zarband Company (Table 1). The Cumin oil was obtained by steam distillation of seed. Ground seed were sieved and then subjected to water distillation using a Clevenger apparatus ( 3 hours) (Beis et al., 2000).

The cumin EO was diluted with distilled water (0, 1.56, 3.13, 6.25, 12.5 and $25 \mathrm{ppm}$ ) and the radishes were immersed at $20^{\circ} \mathrm{C}$ for $10 \mathrm{~min}$. Then all radishes were air-dried under room temperature for $1 \mathrm{~h}$, put in polyethylene plastic containers (10 tubers per each container) and placed in the cold storage $\left(5^{\circ} \mathrm{C}, 95 \%\right.$ $\mathrm{RH})$. The tubers were selected for the following measurements at $0,3,6$ and 9 days of storage. 
Table 1 - Physicochemical and microbiology of analysis of Cumin EO

\begin{tabular}{lc}
\hline Test & Results \\
\hline Physicochemical test & Clear liquid \\
Appearance & Pale Yellow \\
Color & Confirmed characteristics \\
Odor & $0.89 \mathrm{Kg} \mathrm{m}^{-3}$ \\
Density & 1.46 \\
Refractive index & $36.33 \%$ \\
Assay (Cumin aldehyde) & \\
Microbiology limit test & $<10$ Colony Forming Units per $\mathrm{mL}$ \\
Total bacterial count & Absence \\
Total mold and yeasts & Absence \\
Escherichia coli & Colony Forming Units per $\mathrm{mL}$ \\
Salmonellae &
\end{tabular}

Plant used parts: fruits, state: liquid.

\section{Color parameters}

Tuber skin color was measured using a colorimeter (Konica-CR-400 Minolta, Japan) under reflected light in CIE L*a*b* system, where $L^{*}$ expressed color lightness from 0 (black) to 100 (white), a*defined the proportion of red $(+a)$ to green $(-a)$, and $b^{*}$ represented the proportion of yellow $(+b)$ to blue $(-b)$. The average of six records was considered for every color parameter.

\section{Malondialdehyde content}

According to Heath and Packer (1968), $0.5 \mathrm{~g}$ of the tuber was homogenized in $5 \mathrm{ml}$ of $1 \%$ Trichloroacetic acid (TCA), centrifuged (10000 rpm, $5 \mathrm{~min}$ ) and the supernatant $(250 \mu \mathrm{l})$ was mixed with $1 \mathrm{ml}$ of Malondialdehyde (MDA) solution containing 20\% TCA and 5\% TBA (Thiobarbituric acid). It was then incubated in a hot water bath $\left(95^{\circ} \mathrm{C}\right)$ for $30 \mathrm{~min}$, immediately cooled and re-centrifuged (10000 rpm, $10 \mathrm{~min}$ ). The absorbance of the sample was measured at 532 and $600 \mathrm{~nm}$ (using a Cecil CE2501 spectrophotometer). The MDA content was calculated using the equation (1).

$$
\operatorname{MDA}\left(\mathrm{mg} \mathrm{g}^{-1} \mathrm{FW}\right)=\left[\left(\mathrm{A}_{532}-\mathrm{A}_{600}\right) \times W \times 1000\right] / 116
$$

Where $A_{532}$ and $A_{600}$ are the sample absorptions at 530 and $600 \mathrm{~nm}$, respectively, $W$ is the sample weight (mg) and 116 is dilution factor

\section{Total phenol content}

The total phenol content was determined by the Folin-Ciocalteu procedure (Spanos and Wrolstad, 1990). Tuber tissue ( $0.5 \mathrm{~g}$ ) was homogenized with 10 $\mathrm{ml}$ of $80 \%$ methanol. The mixture was centrifuged (10000 rpm, for $10 \mathrm{~min}$ ). Then $10 \mu \mathrm{l}$ of the supernatant, $490 \mu$ of distilled water and $500 \mu$ of FolinCiocalteu reagent were mixed and incubated under dark ambient conditions $\left(24 \pm 1^{\circ} \mathrm{C}\right)$ for $3 \mathrm{~min}$. Then 500 $\mu$ of sodium carbonate (1\%) was added and the mixtures were re-incubated under the same conditions for $30 \mathrm{~min}$. The absorbance was measured at $750 \mathrm{~nm}$ using a Cecil CE2501 spectrophotometer and the phenol content was expressed in $\mu$ g gallic acid $\mathrm{g}^{-1} \mathrm{FW}$, using a gallic acid (0-0.1 $\left.\mathrm{mg} \mathrm{ml}^{-1}\right)$ standard curve.

\section{Antioxidant activity (DPPH)}

The DPPH (2,2-Diphenyl-1-Picrylhydrazyl) assay was done according to Singleton et al. (1999) procedure. Briefly, $0.1 \mathrm{~g}$ of tuber tissue was powdered in liquid nitrogen and then $100 \mathrm{ml}$ of $96 \%$ ethanol was added. After centrifuging (at $3500 \mathrm{rpm}, 5 \mathrm{~min}$ ), $950 \mu \mathrm{l}$ of $0.1 \mathrm{~N}$ DPPH was added to $50 \mu \mathrm{l}$ of each sample and stirred immediately. Each sample was then kept in ambient dark conditions for 30 min. Finally, the absorption of the extract was measured at $517 \mathrm{~nm}$. The antioxidant activity was evaluated using equation (2).

Antioxidant activity $(\%)=[($ Acont - Asamp $) /$ Acont $] \times 100$

Where Acont and Asamp are absorptions of the standard and the sample, respectively.

\section{Protein content}

Tuber tissue $(0.1 \mathrm{~g})$ was homogenized in $1 \mathrm{ml}$ of $50 \mathrm{mM}$ sodium phosphate buffer (containing 129.18 mM NAH ${ }_{2} \mathrm{PO}_{4}, 383.96 \mathrm{mM} \mathrm{NA}_{2} \mathrm{HPO}_{4}, 12.66 \mathrm{mM}$ EDTA, $\mathrm{pH}=7)$. The homogenates were then centrifuged (10000 rpm, $4^{\circ} \mathrm{C}$ for $10 \mathrm{~min}$ ). The Bradford solution (1 $\mathrm{ml})$ was added to the supernatant $(50 \mu \mathrm{l})$ and the absorbance was measured at $595 \mathrm{~nm}$. The protein content was evaluated according to the standards curve of Bovine serum albumin (BSA) and expressed in $\mathrm{mg} \mathrm{g}^{-1}$ fresh weight (Bradford, 1976).

The assay of protease, catalase, peroxidase and polyphenol oxidase activities

The radish tuber $(0.5 \mathrm{~g})$ was powdered with liquid nitrogen and mixed with $1 \mathrm{ml}$ of the extraction solution (containing $100 \mathrm{ml}$ of $50 \mathrm{mM}$ phosphate buffer, $1.27 \mathrm{mM}$ of EDTA and 4Mm of PVP). The mixture was then centrifuged (1000 rpm, $15 \mathrm{~min}$ ). Afterwards the supernatant, as an enzyme extract, was used for determining the activity of the following enzymes (Dhindsa et al., 1981).

The protease activity was determined using a pro- 
cedure defined by Homaei and Samari (2017). Briefly, $50 \mu \mathrm{l}$ of the enzyme extract was mixed with $350 \mu \mathrm{l}$ of $50 \mathrm{mM}$ sodium phosphate buffer $(\mathrm{pH}=7.5)$ and then $800 \mu \mathrm{l}$ of $1 \%$ casein was added. The mixture was incubated for $10 \mathrm{~min}$ at ambient temperature. Then 400 $\mu \mathrm{l}$ of $10 \%$ TCA was added and the mixture was again re-incubated at ambient temperature for $20 \mathrm{~min}$. Finally, the samples were centrifuged (10000 rpm, 10 $\mathrm{min}$ ) and the absorption at $280 \mathrm{~nm}$ was measured. The coefficient of excitation was $26.40 \mathrm{mM}^{-1} \mathrm{~cm}^{-1}$.

To assay the catalase activity, $50 \mu$ l of the enzyme extract was mixed with $1 \mathrm{ml}$ of the catalase reaction solution (containing $50 \mathrm{mM}$ phosphate buffer with $\mathrm{pH}=7$ and $15 \mathrm{mM} \mathrm{H}_{2} \mathrm{O}_{2}$ ). Then the absorption was measured at $240 \mathrm{~nm}$ and the coefficient of excitation was $39.4 \mathrm{mM}^{-1} \mathrm{~cm}^{-1}$ (Dhindsa et al., 1981).

To determine the peroxidase activity, $33 \mathrm{ml}$ of the enzyme extract was mixed with $1 \mathrm{ml}$ of peroxidase reaction solution (containing $13 \mathrm{mM}$ guaiacol, $5 \mathrm{mM}$ $\mathrm{H}_{2} \mathrm{O}_{2}$ and $50 \mathrm{mM}$ phosphate-potassium buffer with $\mathrm{pH}=7$ ). The sample absorption was then measured at $470 \mathrm{~nm}$ and the coefficient of excitation was 26.6 $\mathrm{mM}^{-1} \mathrm{~cm}^{-1}$ (Chance and Maehly, 1995).

In order to assay the polyphenol oxidase (PPO) activity, $100 \mu \mathrm{l}$ of the enzyme extract was mixed with $1 \mathrm{ml}$ of pyrogallol reaction solution (containing $2.5 \mathrm{ml}$ of $50 \mathrm{mM}$ potassium phosphate buffer and $200 \mu \mathrm{l}$ of $0.2 \mathrm{M}$ pyrogallol). The sample absorbance was then measured at $280 \mathrm{~nm}$ and the coefficient of excitation was $26.4 \mathrm{mM}^{-1} \mathrm{~cm}^{-1}$ (Kar and Mishra, 1976).

\section{Data analysis}

The statistical analysis was done using SAS (version 9.1.3) (SAS Institute Inc. Cary, NC, USA, 1990). The Shapiro-Wilks test confirmed the data normality (procedure: PROC UNIVARIATE, SAS). The Multivariate Analysis of Variance was performed related to the observation period and cumin levels, both of which were considered as independent variables (procedure: PROC GLM, SAS). Pillai's trace test confirmed the variance homogeneity (procedure: PROC GLM, SAS). Tukey's test was used in order to compare the mean values (procedure: Files, Sedit, Factor, Range, $\mathrm{P}<0.01$, MSTATC). Excel 2013 was used to draw the figures. The presented mean values are the average of two growing seasons.

\section{Results}

\section{Color parameters}

The results indicated that all color parameters were influenced during the observation period. A declining trend was observed in the $L^{*}$ value after nine days of storage. The highest $L^{*}$ value $(35.1 \pm 0.56)$ was observed on day 0 (in control plants) and the lowest value $(23.19 \pm 0.97)$ on 9 days (in control plant). However, over the storage period of tubers, this factor increased in cumin EO treated tubers. Increase of $17.43 \%$ and $17.32 \%$ in $L^{*}$ value in the 9 days of treatment was the results of 12.5 and $25 \mathrm{ppm}$ cumin EO application, respectively (Fig. 1A).

The results indicated that over the storage period, the $a^{*}$ trend was declining. The highest $(30.32 \pm 0.75)$ and the lowest $(19.35 \pm 0.88)$ values were observed on the 0 and 9 days, respectively, in the control after being under cold storage. But, increasing the concentration of cumin EO in each measurement period (3, 6 and 9 days), led to an increase in a* value. Based on the results, the highest value ( $29.42 \%$ increment) occurred at 25 ppm cumin EO on 3 days (Fig. 1B).

According to our results the $b^{*}$ value showed an ascending trend and rose from $10.5 \pm 0.65$ on day 0 to $16.87 \pm 0.59$ on 9 days of $25 \mathrm{ppm}$ EO treatment. Moreover, increase in the concentration of cumin EO made significant increments in $b^{*}$ value $18.37 \%$,
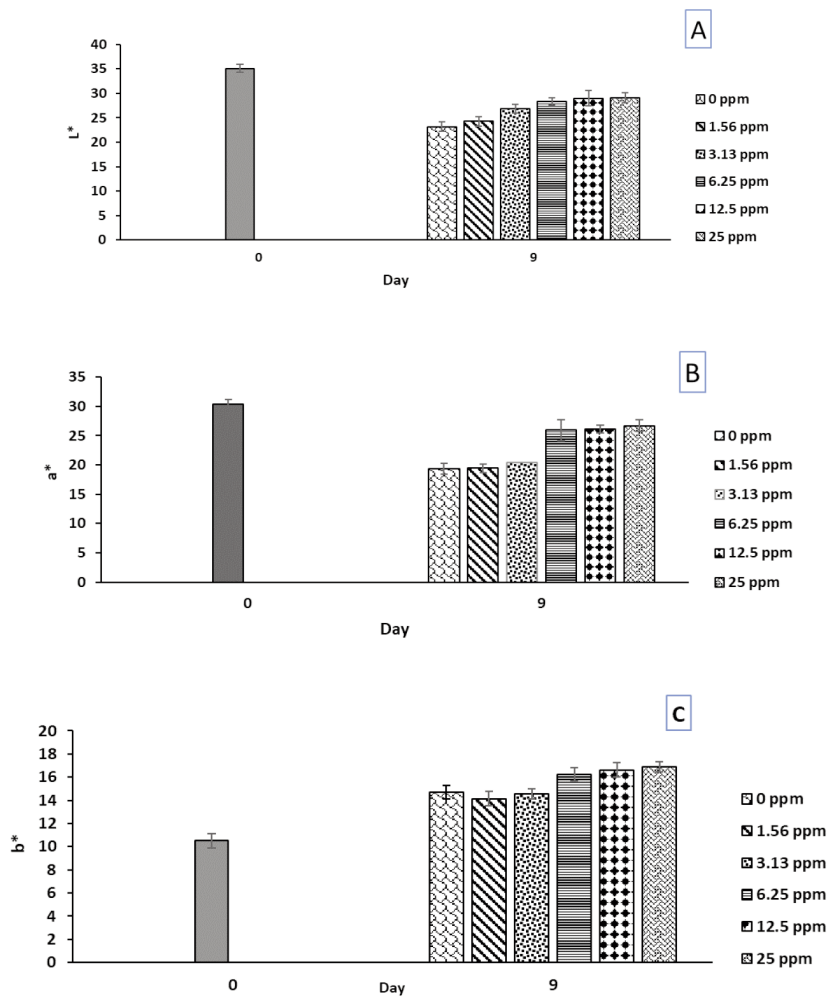

Fig. 1 - The influence of cumin EO concentrations on the $L^{*}(A)$, $a^{*}(B)$, and $b^{*}(C)$ values under different observation periods in cold stored-radishes. Means \pm SD of six replicates of two seasons are given (Tukey, $p<0.01$ ). 
$3.43 \%$ and $12.64 \%$, respectively on 3,6 and 9 days) (Fig. 1C).

\section{MDA, phenol contents and antioxidant activity}

The MDA and phenol contents, along with the antioxidant activity, were significantly affected by the EO levels and storage duration. During the nine days of radish storage, the MDA, total phenol content and the antioxidant activity showed ascending trend. Furthermore, the cumin EO treatment resulted in a significant reduction in MDA and phenol contents (Figs. 2A, B).

According to our findings, malondialdehyde generally increased as a result of storage period extent. The MDA content of the first assessment, day 0 , $\left(0.75 \pm 0.16 \mathrm{mg} \mathrm{g}^{-1}\right.$ fresh weight) rose to $3.29 \pm 0.15 \mathrm{mg}$ $\mathrm{g}^{-1}$ fresh weight in the last assessment ( 9 days of storage). The cumin EO-treated tubers had $0.76 \pm 0.14 \mathrm{mg}$ $\mathrm{g}^{-1}$ fresh weight MDA content at $25 \mathrm{ppm}$ on 9 days. However, in each assessment period, a declining trend in malondialdehyde content was a result of increment in the concentration of cumin EO. The highest amount of MDA was related to the control treatment value on the 9 days $\left(3.29 \pm 0.15 \mathrm{mg} \mathrm{g}^{-1}\right.$ fresh
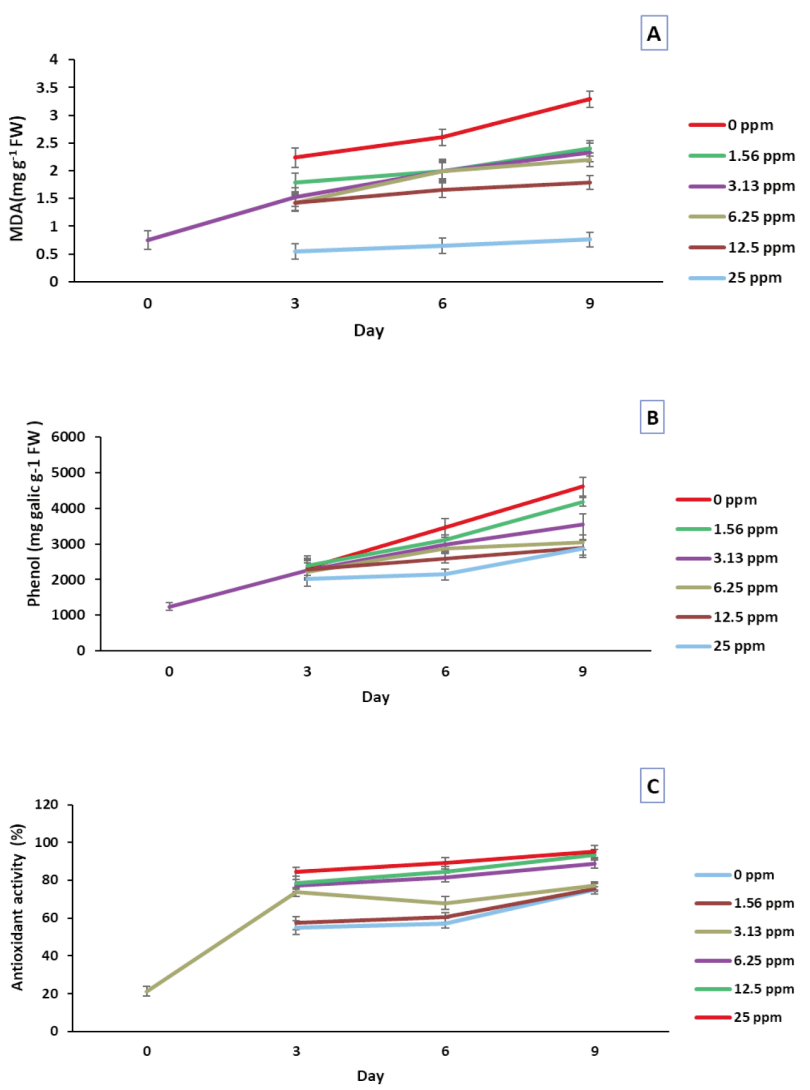

Fig. 2 - The influence of cumin EO concentrations on the MDA $(A)$, phenol content (B), and antioxidant activity (C) under different observation periods in cold-stored radishes. weight) and the lowest value $\left(0.55 \pm 0.14 \mathrm{mg} \mathrm{g}^{-1}\right.$ fresh weight) was recorded at the $25 \mathrm{ppm}$ cumin EO on the 3 days (Fig. 2A).

The results indicated that the total phenol content showed an increasing trend over the storage period. The phenol content rose from $1243 \pm 116.19$ $\mu \mathrm{g}$ of gallic acid $\mathrm{g}^{-1}$ fresh weight, in the first observation (day 0) to $4613.05 \pm 258.90 \mu \mathrm{g}$ of gallic acid $\mathrm{g}^{-1}$ fresh weight on the last day of storage. Although, the total phenol content showed a declining trend, with increasing the concentration of cumin EO. The lowest content of total phenol was observed at $25 \mathrm{ppm}$ cumin EO on the 3 days (2024.03 $\pm 212.84 \mu \mathrm{g}$ of gallic acid g $^{-1}$ fresh weight). (Fig. 2B).

Regarding the antioxidant activity, over the duration of storage period and also with increasing the concentration of cumin EO, an ascending trend was observed compared to the control. The value of antioxidant activity on day $0(21.2 \pm 2.49 \%)$ for control plants, improved significantly on days 3 (54.98 $\pm 3.62 \%), 6(57.19 \pm 3.33 \%)$ and $9(75.24 \pm 1.41 \%)$. The $25 \mathrm{ppm}$ cumin treated-tubers showed a same trend, which was reached from $84.37 \pm 2.41 \%$ on 3 days to $95.18 \pm 3.07 \%$ on 9 days (Fig. 2 C).

\section{Protein content and enzyme activities}

The effect of low temperature storage on the radishes caused in the reduction in the protein content along with an increase in the activity of protease. Different levels of cumin EO in each observation period had a significant effect on both traits (Figs. 3A, B). The results indicated that the protein content decreased over the storage period of radish. The protein content in the control treatment on the day 0 measurement was $27.1 \pm 0.33 \mathrm{mg} \mathrm{g}^{-1}$ fresh weight and reached to $15.48 \pm 0.94 \mathrm{mg} \mathrm{g}^{-1}$ on the 9 days. The highest content of protein was related to $1.56 \mathrm{ppm}$ cumin EO (26.78 $\pm 0.33 \mathrm{mg} \mathrm{g}^{-1}$ fresh weight) on the 3 days and the lowest content was related to $3.13 \mathrm{ppm}$ cumin EO (26.4 $\pm 0.32 \mathrm{mg} \mathrm{g}^{-1}$ fresh weight). On the 6 and 9 days of storage, the highest value was occurred in 25 ppm cumin EO $(25.29 \pm 1.22$ and $19.40 \pm 1.32 \mathrm{mg} \mathrm{g}^{-1}$ fresh weight increment) (Fig. 3A).

The protease activity on day $0(1.1 \pm 0.16 \mu \mathrm{mol}$ $\mathrm{min}^{-1} \mathrm{~g}^{-1}$ fresh weight) had an ascending trend during 9 days of cold storage. Also increasing the concentrations of cumin EO (6.25 $\pm 0.11 \mathrm{ppm}$ and more), increased the protease activity. This trait was varied from $1.35 \pm 0.15$ to $2.53 \pm 0.20 \mu \mathrm{mol} \mathrm{min} \mathrm{m}^{-1} \mathrm{~g}^{-1}$ fresh weight on the 3 days and from $4.93 \pm 0.11$ to $6.93 \pm 0.14 \mu \mathrm{mol} \mathrm{min} \mathrm{m}^{-1}$ fresh weight on the 6 days, as a result of different cumin EO levels. However, on 
the 9 days of storage, the protease activity varied from $9.55 \pm 0.11$ to $11.9 \pm 0.15 \mu \mathrm{mol} \mathrm{min}{ }^{-1} \mathrm{~g}^{-1}$ fresh weight as a result of different EO concentrations (Fig. 3B).
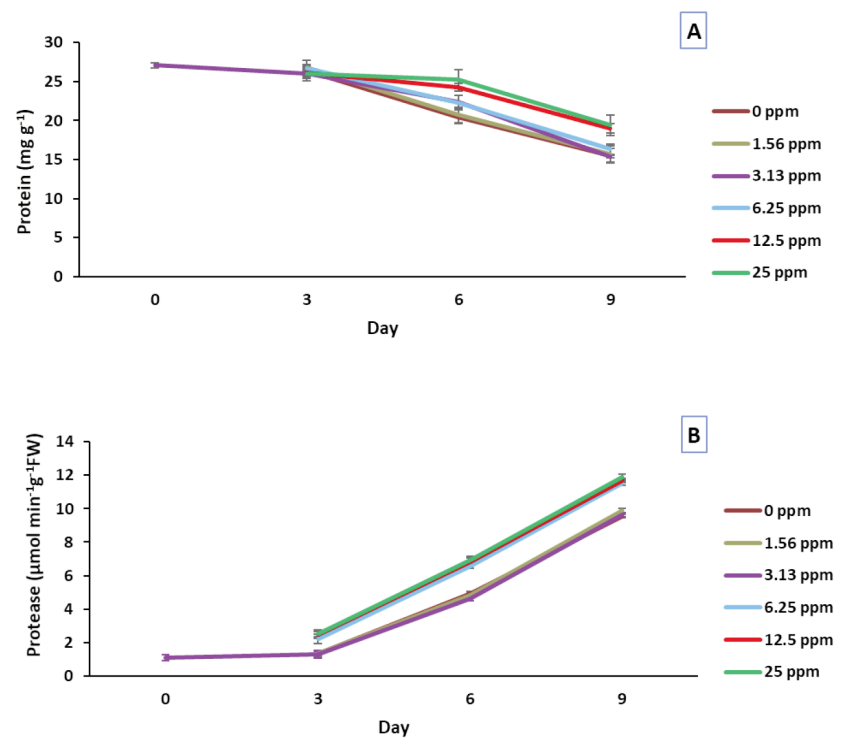

Fig. 3 - The influence of cumin EO concentrations on the protein content (A) and the activity of protease (B) under different observation periods in cold stored-radishes. Means \pm SD of six replicates of two seasons are given (Tukey, $p<0.01)$.

There were enhancements in the activities of radish antioxidant enzymes (Figs. 4A, B, C). According to figure $4 A$, a weak increment was observed in the catalase activity, by increasing the storage days until 6 days. Nonetheless, the first measurement did not differ much than the second measurement. However, on 9 days, the highest activity was observed in all concentrations compared to the control. Different concentrations of cumin EO showed various patterns on different days. On 3 days, the lowest catalase activity was observed in the control $(106.34 \pm 12.39$ $\mu \mathrm{mol} \mathrm{min}^{-1} \mathrm{~g}^{-1}$ fresh weight) and the highest was at $1.56 \mathrm{ppm}$ cumin EO $\left(132.51 \pm 22.27 \mu \mathrm{mol} \mathrm{min} \mathrm{m}^{-1}\right.$ fresh weight). The highest enzyme activity on the 6 days was at $3.13 \mathrm{ppm}\left(209.40 \pm 18.38 \mu \mathrm{mol} \mathrm{min}^{-1} \mathrm{~g}^{-1}\right.$ fresh weight) and the lowest was at $6.25 \mathrm{ppm}$ (202.27 $\pm 17.46 \mu \mathrm{mol} \mathrm{min}{ }^{-1} \mathrm{~g}^{-1}$ fresh weight). On 9 days, the trend was completely declining, as the highest enzyme activity was in the control $(1013.45 \pm 19.26$ $\mu \mathrm{mol} \mathrm{min}^{-1} \mathrm{~g}^{-1}$ fresh weight) and the lowest was observed at $25 \mathrm{ppm}$ cumin EO $(602.72 \pm 19.07 \mu \mathrm{mol}$ $\mathrm{min}^{-1} \mathrm{~g}^{-1}$ fresh weight) (Fig. 4A).

Peroxidase activity increased over the storage period and changed from $78.23 \pm 2.4 \mu \mathrm{mol} \mathrm{min}^{-1} \mathrm{~g}^{-1}$ fresh weight on day 0 to $178.94 \pm 4.39 \mu \mathrm{mol} \mathrm{min}{ }^{-1} \mathrm{~g}^{-1}$ fresh weight in the last observation (9 days). In addi-
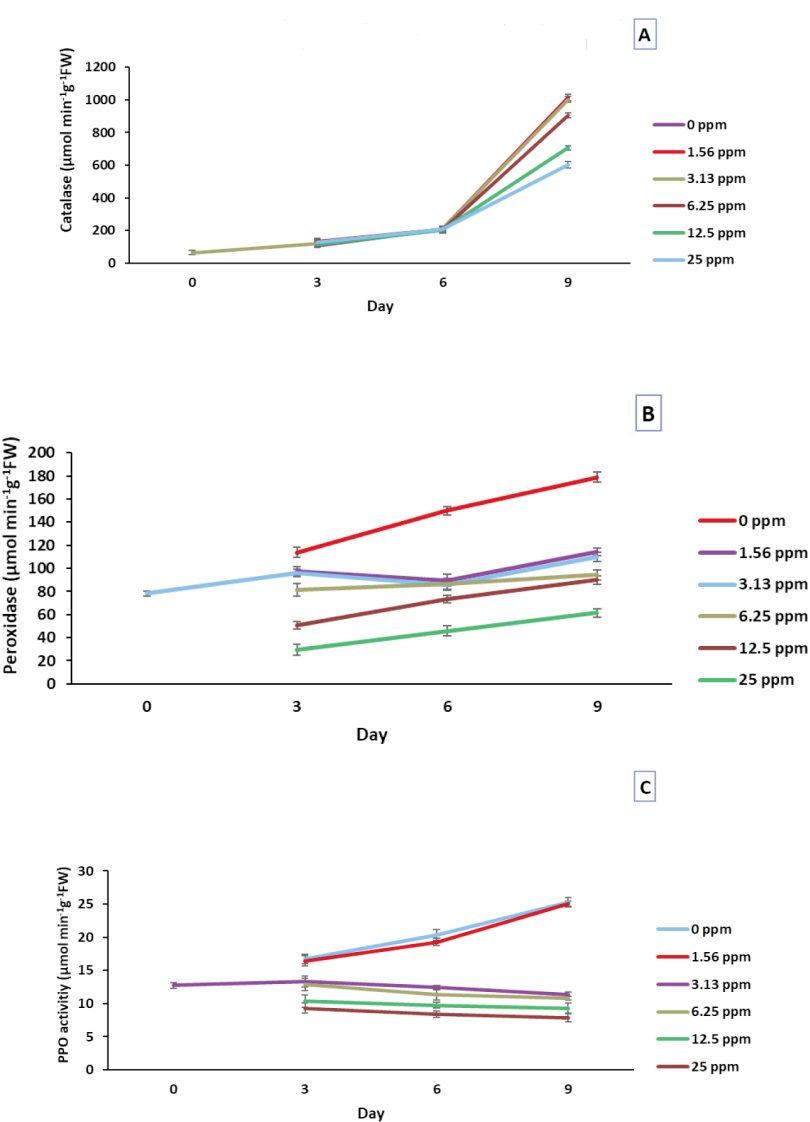

Fig. 4 - The influence of cumin EO concentrations on the activity of catalase (A), peroxidase (B), and PPO (C) under different observation periods in cold-stored radishes. Means \pm SD of six replicates of two seasons are given (Tukey, $\mathrm{p}<0.01)$.

tion, increasing in the EO concentration reduced the activity of this enzyme. Accordingly, the lowest values $(29.81 \pm 4.73,45.90 \pm 4.42$ and $61.41 \pm 3.76 \mu \mathrm{mol}$ $\mathrm{min}^{-1} \mathrm{~g}^{-1}$ fresh weight) of the peroxidase activity were observed at 25 ppm cumin EO on the 3, 6 and 9 days, respectively and the highest activity was in the control $(113.80 \pm 4.60,149.79 \pm 3.72$ and $178.94 \pm 4.39$ $\mu \mathrm{mol} \mathrm{min}^{-1} \mathrm{~g}^{-1}$ fresh weight, respectively) on 3, 6 and 9 days, respectively (Fig. 4B).

The activity of polyphenol oxidase enzyme increased over the storage days (from day 0 to 9 days) at zero and $1.56 \mathrm{ppm}$; as the highest activity (25.31 $\pm 0.73 \mu \mathrm{mol} \mathrm{min}^{-1} \mathrm{~g}^{-1}$ fresh weight) was observed in cumin EO-free tubers on 9 days. Changes in the activity of polyphenol oxidase on 3 and 6 days showed similar trends. Its activity on day 0 $\left(12.76 \pm 0.45 \mu \mathrm{mol} \mathrm{min}{ }^{-1} \mathrm{~g}^{-1}\right.$ fresh weight) rose to $25.31 \pm 0.73 \mu \mathrm{mol} \mathrm{min}{ }^{-1} \mathrm{~g}^{-1}$ fresh weight on the 9 days. In the cumin EO treated tubers, the PPO activity indicated a declining trend, over time and the lowest activity $\left(8.44 \pm 0.49 \mu \mathrm{mol} \mathrm{min} \mathrm{m}^{-1} \mathrm{~g}^{-1}\right.$ fresh weight) was observed at 25 ppm, on 6 days (Fig. 4C). 


\section{Discussion and Conclusions}

Excess production of ROS and oxidative burst, under cold conditions, elicit some plant physiological reactions. The formed ROS interact with cellular components, trigger cascade of oxidative responses, peroxidase lipids, degrade proteins, inactivate enzymes and damage the DNA (Mittler, 2002). Exposure to cold conditions causes the discoloration of radish and production of cracks on its edible parts (Abdel, 2016). In addition, low temperatures influence carbohydrate accumulation in radish roots, accelerate plant growth rates and increase the shoot/root biomass ratio (Sirtautas et al., 2011).

Color is an important factor in the consumer's acceptance of foods. The $L^{*}, a^{*}$ and $b^{*}$ values describe color parameters of food products (Walkowiak-Tomczak et al., 2008). The color of stored-fruits and vegetables mostly changes and turns darker over time. Hernandez-Munoz etal. (2008) reported a decrease in the values of color indices of cold stored-strawberry fruits. In the present study, there was a significant reduction in $L^{*}$ and $a^{*}$ values, despite an increase in $b^{*}$ of radish tubers through storage period, which was related to a reduction in water content and product browning (Hassani etal., 2012).

The impact of organic compounds on the color characteristics of horticultural products has been reported previously (Raybaudi-Massilia etal., 2008; Asghari Marjanlo et al., 2009). Clove EO prevented browning of grapes by preventing water loss (Martinez-Romero et al., 2007). According to our findings, treatment with different cumin EO concentrations caused different color values in the radishes.

Cold disturbs the electron transfer chain in mitochondria and chloroplasts. This happens by an excess production of ROS and causes oxidative damage to the membrane, thereby accelerates the lipid peroxidation and MDA over production (Larkindale and Huang, 2004). The results of this study showed a significant increase in the malondialdehyde content during the nine days of cold storage. Antioxidant compounds inhibit free radical's generation, interrupt its functions or lead to ROS destruction (Melo et al., 2005; Srivsatava et al., 2011). The cinnamon EO has reportedly prevented the membrane lipids peroxidation in peaches (Montero-Prado et al., 2011). Our findings regarding the cold-stored radishes treated with cumin EO, confirm this finding.

In this work, the antioxidant capacity of coldstored radishes was assayed using the scavenging ability of DPPH radicals, which is used widely for evaluating the radical scavenging effects of chemical and organic materials. DPPH functions by absorbing electrons or hydrogens, thereby becomes a stable molecule (Sagar and Sing, 2011). The results indicated that the scavenging capacity of cumin-treated tubers was significantly higher than those of the control, proving that cumin improved the scavenging ability in radish tubers. According to our results, cumin EO displayed a dose-dependent manner in the scavenging of free radicals, as previously reported by Dua et al. (2012). Similarly, the antioxidant properties of peppermint and clove oils can be attributed to the ability of free radical scavenging (Tripathi and Dubey, 2004).

Polyphenol compounds naturally show an ability to scavenge ROS. They are considered to be the effective non-enzymatic antioxidants (Ma et al., 2011; Zrig et al., 2011).

The application of organic compounds was reportedly capable in improving the phenol content of coldstored mangoes (Wang and Lin, 2000; Razzaq et al., 2015). This can occur through changes in both polyphenol oxidase (PPO) and phenylalanine ammonia-lyase (PAL) activities (Sun et al., 2010; Deng et al., 2015). In our work, keeping the radish tubers in cold storage conditions made an increase in their phenol content. The application of cumin EO improved the antioxidant capacity and gradually decreased the phenol content.

The lethal impact of oxidative stress on biological organisms is correlated to the destruction of proteins and the inactivation of enzymes (Srivsatava et al., 2011). In the present study, the cold stored radishes displayed a visible decrease in protein content and an increase in antioxidant enzyme activities. The antioxidant enzymes act as agents that trigger detoxification at low temperatures (Mittler, 2002) and convert free radicals to the compounds that eventually release water and oxygen (Zheng and Tian, 2006). Superoxide dismutase detoxifies ROS by generating $\mathrm{H}_{2} \mathrm{O}_{2}$. Then, ascorbate peroxidase and catalase breakdown the $\mathrm{H}_{2} \mathrm{O}_{2}$ (Wang, 1995). Catalase converts free radicals to oxygen and water (Zheng and Tian, 2006). Our results of increases in catalase, peroxidase and PPO activities in cold stored radishes, confirmed the previous researches.

Essential oils can be considered as agents that aid the antioxidant defense system, reduce the release of radicals, prevent the destruction of cells and thus increase stress tolerance of plants (Holley and Patel, 2005). The usage of carvacrol and anethole in raspberry causes a reduction in antioxidant enzyme activ- 
ity (Jin et al., 2012). Lipoxygenase activity is also reported to be reduced in cinnamon-treated peaches (Montero-Prado et al., 2011).

Microbiology limit test confirmed that bacteria, mold and yeasts in our essential oil sample can be ignored. Also it has no Salmonellae neither Escherichia.coli. The density of cumin essential oil is 0.90 (Lewis, 1999). The pale yellow color and strong odor of our essential oil sample was similar to standard reference. Cumin seeds contain flavonoids $(\beta-$ pinene, $\mathrm{p}$-cymene, cumin aldehyde and cuminyl alcohol) are recognized to have antioxidant activity and scavenging capacity of the superoxide anion (Sowbhagya 2013). The refractive index of an essential oil is a unique number that designates how the oil responds to and bends light. Essentially, it is a measurement that tests how the speed of light is altered when passing through the oil. The refractive index of our essential oil sample (1.48) and cumin aldehyde content (36.33\%) were close to which reported earlier (1.49 and 45\%, respectively) (Fahlbusch et al., 2005). Cumin aldehyde is a constituent of the essential oils of eucalyptus, myrrh and cumin (Morshedi et al., 2015). $\beta$-pinene is a monoterpene, an organic compound found in cumin essential oil (Li and Jiang, 2004). The presence of polyphenolic compounds in cumin EO inhibits protein oxidation and enzyme inactivation (Melo et al., 2005). According to our findings, cumin EO improved the antioxidant system of tubers so caused in decreased catalase, peroxidase and PPO activities.

The market for chilled-fresh products has a dramatic rise in the recent decade, encouraged mostly by the consumer request for nutritious, fresh and additive-free products. Hence, the food industry has to respond with novel preservation, storage and handling strategies. In our study, the storage of greenhouse-harvested radishes at low temperatures declined the $\mathrm{L}^{*}$ and $\mathrm{a}^{*}$ values, and protein content during nine-day of storage, but increased the $b^{*}$ value, phenol content, antioxidant capacity, MDA level, PPO, peroxidase, catalase and protease activities. The application of cumin EO reduced the MDA content, polyphenol oxidase and peroxidase activities. Finally, cold-stored radishes received the most effective treatment of cumin EO at the concentration of 12.5 and $25 \mathrm{ppm}$.

\section{Acknowledgements}

The authors thank the Head of Research and
Technology Center, University of Hormozgan for their financial support and Miss Razie Esfandiari Ghalati for her technical assistance.

\section{References}

ABDEL C.G., 2016 - Physiological disorders of four radishes (Raphanus sativus L. var. sativus) cultivars storage roots grown in controlled cabinets under varying temperatures and irrigation levels.- Int. J. Farming and Allied Sci., 5(2): 185-198.

ANDRE'C., CASTANHEIRAA A.I., CRUZB J.M., PASEIROB P., SANCHES-SILVA A., 2010 - Analytical strategies to evaluate antioxidants in food: a review. - Trends in Food Sci. \& Technol., 21: 229-246.

ASGHARI MARJANLO A., MOSTOFI Y., SHOEIBI S., FATTAHI M., 2009 - Effect of cumin essential oil on postharvest decay and some quality factors of strawberry. - J. Med. Plants, 3(31): 25-43.

AYUB R.A., SPINARDI B., GIOPPO M., 2013 - Storage and fresh cut radish. - Acta Sci.- Agronomy Maringá, 35(2): 241-245.

BAENAS N., PIEGHOLDT S., SCHLOESSER A., MORENO D., GARCÍA-VIGUERA C., RIMBACH G., WAGNER A., 2016 Metabolic activity of radish sprouts derived isothiocyanates in drosophila melanogaster. - Int. J. Molecular Sci., 17(2): 1-10.

BANIHANI S.A., 2017 - Radish (Raphanus sativus) and diabetes. - Nutrients, 9: 1-9.

BEIS SH., ESKISEHIR N.A., OZEK T., HUSNU K., 2000 - The production of essential oil from Cumin seeds. - Chem. Natural Compounds, 36(3): 256-268.

BRADFORD M.M., 1976 - A rapid and sensitive method for the quantitation of microgram quantities of protein utilizing the principle of protein-dye binding. - Analytical Biochem., 72(1-2): 248-254.

CHANCE B., MEAHLY A.C., 1995 - Assay of catalase and peroxidase. - Series. Methods in Enzymology, Academic press. Inc. New York, USA, pp. 764-775.

DEL AGUILA J.S., SASAKI F.F., HEIFFIG L.S., ORTEGA E.M.M., JACOMINO A.D., KLUGE R.A., 2006 - Fresh-cut radish using different cut types and storage temperatures. Postharvest Biol. Technol., 40: 149-154.

DEL AGUILA J.S., SASAKI F.F., HEIFFIG L.S., MOISÉS E., ORTEGA M., TREVISAN M.J., KLUGE R.A., 2008 - Effect of antioxidants in fresh cut radishes during the cold storage. - Brazilian Archives Biol. Technol., 51: 1217-1223.

DENG J., BI Y., ZHANG Z., XIE D., GE Y., LI W., WANG J., WANG Y., 2015 - Postharvest oxalic acid treatment induces resistance against pink rot by priming in muskmelon (Cucumis melo L.) fruit. - Postharvest Biol. Technol., 106: 53-61.

DHINDSA R.S., PLUMB-DHINDSA P., THORPE T.A., 1981 Leaf senescence: correlated with increased levels of membrane permeability and lipid peroxidation, and 
decreased levels of superoxide dismutase and catalase. - J. Exp. Bot., 32(1): 93-101.

DUA A., GUPTA S.K., MITTAL A., MAHAJAN R.,2012 - A study of antioxidant properties and antioxidant compounds of cumin (Cuminum cyminum). - Int. J. Pharm. Biol. Arch., 3(5): 1110-1116.

FAHLBUSCH K.G., BELLUSSI G., BOHNET M., BUS J., DRAUZ K., GREIM H., JACKEL K.P., KARST U., KLEEMANN A., KREYSA G., LAIRD T., MEIER W., OTTOW E., ROPER E., SCHOLTZ J., SUNDMACHER K., ULBER R., WIETELMANN U., 2005 - Ullmann's Encyclopedia of Industrial C Chemistry. $7^{\text {th }}$ edition. - Wiley \& Sons, Flavors and Fragrances, NY, NY, USA.

GACHKAR L., YADEGARI D., REZAEI M.B., TAGHIZADEH M., ASTANEH S.A., RASOOLI I., 2007 - Chemical and biological characteristics of Cuminum cyminum and Rosmarinus officinalis essential oils. - Food Chem., 102(3): 898-904.

HASSANI A., FATHI Z., GHOSTA Y., ABDOLLAHI A., MESHKATALSADAT M.H., MARANDI R.J., 2012 Evaluation of plant essential oils for control of postharvest brown and gray mold rots on apricot. - J. Food Safety, 32(1): 94-101.

HEATH R.L., PACKER L., 1968 - Photo peroxidation in isolated chloroplasts: I. Kinetics and stoichiometry of fatty acid peroxidation. - Archives Biochem. Biophysics, 125(1): 189-198.

HERNANDEZ-MUNOZ P., ALMENAR E., DEL VALLE V., VELEZ D., GAVARA R., 2008 - Effect of chitosan coating combined with postharvest calcium treatment on strawberry (Fragariax ananassa) quality during refrigerated storage. - Food Chem., 110(2): 428-435.

HOLLEY R.A., PATEL D., 2005 - Improvement in shelf-life and safety of perishable foods by plant essential oils and smoke antimicrobials. - Food Microbiol., 22(4): 273-292.

HOMAEI A., SAMARI F., 2017 - Investigation of activity and stability of papain by adsorption on multi-wall carbon nanotubes.- Int. J. Biol. Macromol., 105: 1630-1635.

ISHIDA M., KAKIZAKI T., MORIMITSU Y., OHARA T., HATAKEYAMA K., YOSHIAKI H., NISHIO T., 2015 - Novel glucosinolate composition lacking 4-methylthio-3butenyl glucosinolate in Japanese white radish (Raphanus sativus L.). - Theor. Appl. Gen., 128(10): 2037-2046.

JIN P., WANG S.Y., GAO H., CHEN H., ZHENG Y., WANG C.Y., 2012 - Effect of cultural system and essential oil treatment on antioxidant capacity in raspberries. - Food Chem., 132(1): 399-405.

KAR M., MISHRA D., 1976 - Catalase, peroxidase, and polyphenol oxidase activities during rice leaf senescence. -Plant Physiol., 57(2): 315-319.

KHALID S., ABDEL-LATEIF I., MAGHRABI A., HANY A., ELDEAB J. 2016 - The plant natural products: Their antioxidants, free radical scavengers, DNA protection and antimicrobial activities. - Bioprocess Biotech., 6(9):
1-7.

KHATTAK K.F., 2011 - Nutrient composition, phenolic content and free radical scavenging activity of some uncommon vegetables of Pakistan. - Pakistan J. Pharm. Sci., 24(3): 277-283.

LARKINDALE J., HUANG B., 2004 - Changes of lipid composition and saturation level in leaves and roots for heatstressed and heat-acclimated creeping bentgrass (Agrostis stolonifera). - Envir. Exp. Bot., 51(1): 57-67.

LEE M.Y., LEE M.K., PARK I., 2007 - Inhibitory effect of onion extract on polyphenol oxidase and enzymatic browning of taro (Colocasia antiquorum var. esculenta). - Food Chem., 105(2): 528-532.

LEWIS R.J., 1999 - Sax's dangerous properties of industrial materials. - $10^{\text {th }}$ ed. Volumes 1-3, John Wiley \& Sons Inc., New York, NY, USA, V2, pp. 1017.

LI R., JIANG Z.T., 2004 - Chemical composition of the essential oil of Cuminum cyminum L. from China. - Flavor and Fragrance J., 19(4): 311-313.

LIANG SH., KUANG J.F., JI SH., CHEN, QF., DENG, W., MIN T., SHAN W., CHEN JY., LU WJ. 2020 - The membrane lipid metabolism in horticultural products suffering chilling injury. - Food Quality and Safety, 4: 9-14.

LUENGO R.F.A., CALBO A.G., 2001 - Armazenamento de hortaliças. - Embrapa Hortaliças Brasília, pp. 242.

MA X., WU H., LIU L., YAO Q., WANG S., ZHAN R., ZHOU Y., 2011 - Polyphenolic compounds and antioxidant properties in mango fruits. - Sci. Hort., 129(1): 102-107.

MALIK M.S., RILEY M.B., NORSWORTHY J.K., BRIDGES JR., W., 2010 - Variation of glucosinolates in wild radish (Raphanus raphanistrum) accessions. - J. Agric. Food Chem., 58(22): 11626-11632.

MARTINEZ-ROMERO D., GUILLÉN F., VALVERDE J.M., BAILÉN G., ZAPATA P., SERRANO M., CASTILLO S., VALERO D., 2007 - Influence of carvacrol on survival of Botrytis cinerea inoculated in table grape. - Int. J. Food Microbiol., 115: 144-148.

MELO E.A., FILHO J.M., GUERRA N.B., 2005 Characterization of antioxidant compounds in aqueous coriander extract (Coriandrum sativum L.). - LWT. Food Science and Technology, 38(1): 15-19.

MILAN K.M., DHOLAKIA H., TIKU P.K., VISHVESHWARAIAH P., 2008 - Enhancement of digestive enzymatic activity by cumin (Cuminum cyminum L.) and role of spent cumin as a bio-nutrient. - Food Chem., 110(3): 678-683.

MISHARINA T.A., SAMUSENKI A.L., 2008 - Antioxidant properties of essential oils from lemon, grapefruit, coriander, clove and their mixtures. - Appl. Biochem. Microbiol., 45: 438-442.

MITTLER R., 2002 - Oxidative stress, antioxidants and stress tolerance. - Trends Plant Sci., 7(9): 405-410.

MONTERO-PRADO P., RODRIGUEZ-LAFUENTE A., NERIN C., 2011 - Active label-based packaging to extend the shelf-life of "Calanda" peach fruit: Changes in fruit quality and enzymatic activity. - Postharvest Biol. Technol., 60(3): 211-219. 
MORSHEDI D., ALIAKBARI F., TAYARANIAN-MARVIAN A., FASSIHI A., PAN-MONTOJO F., PÉREZ-SÁNCHEZ H., 2015 - Cuminaldehyde as the major component of Cuminum cyminum, a natural aldehyde with inhibitory effect on alpha-synuclein fibrillation and cytotoxicity. J. Food Sci., 80(10): H2336-H2345.

NAKAMURA Y., NAKAMURA K., ASAI Y., WADA T., TANAKA K., MATSUO T., PARK E.Y., 2008 - Comparison of the glucosinolate-myrosinase systems among daikon (Raphanus sativus, Japanese white radish) varieties. - J. Agric. Food Chem., 56(8): 2702-2707.

NICOLA S., FONTANA E., HOEBERECHTS J., SAGLIETTI D., 2004 - Raphanus sativus production in soilless or traditional culture systems and postharvest packaging. Acta Horticulturae, 682: 1303-1310.

PATEL Y.N., TANDEL A.H., PATEL B., PATEL L., 2016 Chilling injury in tropical and subtropical fruits: a cold storage problem and its remedies: a review bhoomika. Inter. J. Sci., Environ. Technol., 5(4): 1882-1887.

PAWLIK A., WAŁA M., HAĆ A., FELCZYKOWSKA A., HERMAN-ANTOSIEWICZ A., 2017 - Sulforaphene, an isothiocyanate present in radish plants, inhibits proliferation of human breast cancer cells. - Phytomedicine, 29: 110.

RAVI R., PRAKASH M., BHAT K.K., 2013 - Characterization of aroma active compounds of cumin (Cuminum cyminum L.) by GC-MS, E-Nose, and Sensory Techniques. - Int. J. Food Properties, 16:1048-1058.

RAMACHANDRAN P., PARVATHY K., RAGHURAM M., NAGARAJAN S., 2013 - Chitosan based powder coating technique to enhance phyto-chemicals and shelf life quality of radish shreds.- Postharvest Biol. Technol., 86: 402-408.

RAYBAUDI-MASSILIA R.M., MOSQUEDA-MELGAR J., MARTÍN-BELLOSO O., 2008 - Edible alginate-based coating as carrier of antimicrobials to improve shelf-life and safety of fresh-cut melon. - Inter. J. Food Microbiol., 121(3): 313-327.

RAZZAQ K., KHAN A.S., MALIK A.U., SHAHID M., ULLAH S., 2015 - Effect of oxalic acid application on Samar Bahisht Chaunsa mango during ripening and postharvest. - LWT. - Food Sci. Technol., 63(1): 152-160.

SALERNO A., PIERANDREI F., REA E., COLLA G., ROUPHAEL Y., SACCARDO F., 2005 - Floating system cultivation of radish (Raphanus sativus L.): Production and quality. Acta Horticulturae, 697: 87-92.

SAGAR B.K., SINGH R.P., 2011 - Genesis and development of DPPH method of antioxidant assay.- Food Sci Technol., 48(4): 412-422.

SAS, 1990 - SAS ${ }^{\circledR}$ procedures . Version 9.1.3. - SAS Institute, Cary, NC.

SINGLETON V.L., ORTHOFER R., LAMUELA-RAVENTÓS R.M., 1999 - Analysis of total phenols and other oxidation substrates and antioxidants by means of FolinCiocalteu reagent. - Methods in enzymology. Academic Press, 299: 152-178.

SIRTAUTAS R., SAMUOLIENĖ G., BRAZAITYTĖ A.,
DUCHOVSKIS P., 2011 - Temperature and photoperiod effects on photosynthetic indices of radish (Raphanus sativus L.). - Agriculture., 98(1): 57-61.

SOWBHAGYA H.B., 2013 - Chemistry, technology, and nutraceutical functions of cumin (Cuminum cyminum L): An overview. - Critical Reviews Food Sci. and Nutr., 53(1): 1-10.

SPANOS G.A., WROLSTAD R.E., 1990 - Influence of processing and storage on the phenolic composition of Thompson seedless grape juice. - J. Agric. Food Chem., 38(7): 1565-1571.

SRIVSATAVA R., SRIVASTAVA S.P., JAISWAL N., MISHRA A., MAURYA R., SRIVASTAVA A.K., 2011 - Antidiabetic and antidyslipidemic activities of Cuminum cyminum L. in validated animal models. - Medicinal Chemistry Research., 20(9): 1656-1666.

STEINBRECHER A., NIMPTSCH K., HÜSING A., ROHRMANN S., LINSEISEN J., 2009 - Dietary glucosinolate intake and risk of prostate cancer in the EPIC-Heidelberg cohort study. - Inter. J. Cancer, 125(9): 2179-2186.

SUN D., LIANG G., XIE J., LEI X., MO Y., 2010 - Improved preservation effects of litchi fruit by combining chitosan coating with ascorbic acid treatment during postharvest storage. - African J. Biotech., 9(22): 3272-3279.

THIPPESWAMY N.B., NAIDU K.A., 2005 - Antioxidant potency of cumin varieties-cumin, black cumin and bitter cumin-on antioxidant systems. - European Food Research Technol., 220(5-6): 472-476.

TRIPATHI P., DUBEY N.K., 2004 - Exploitation of natural products as alternative strategy to control post-harvest fungal rotting of fruits and vegetables. - Postharvest Biol. Techn., 32: 235-245.

WALKOWIAK-TOMCZAK D., REGUŁA J., ŁYSIAK G., 2008 Physico-chemical properties and antioxidant activity of selected plum cultivars fruit. - Acta Scientiarum Polonorum Technologia Alimentaria, 7(4): 15-22.

WANG C.Y., 1995 - Effect of temperature preconditioning on catalase, peroxidase, and superoxide dismutase in chilled zucchini squash. - Postharvest Biology and Technology, 5(1-2): 67-76.

WANG N., WANG W., HUO P., LIU C.Q., JIN J.C., SHEN L.Q., 2014 - Mitochondria-mediated apoptosis in human lung cancer a549 cells by 4-methylsulfinyl-3-butenyl isothiocyanate from radish seeds. - Asian Pacific J. Cancer Prevention, 15(5): 2133-2139.

WANG S.Y., LIN H.S., 2000 - Antioxidant activity in fruits and leaves of blackberry, raspberry, and strawberry varies with cultivar and developmental stage. - J. Agricul. Food Chem., 48(2): 140-146.

ZHENG X., TIAN S., 2006 - Effect of oxalic acid on control of postharvest browning of litchi fruit. - Food Chem., 96(4): 519-523.

ZRIG A., TOUNEKTI T., VADEL A.M., MOHAMED H.B., VALERO D., SERRANO M., KHEMIRA H., 2011 - Possible involvement of polyphenols and polyamines in salt tolerance of almond rootstocks. - Plant Physiology and Biochem., 49(11): 1313-1322. 